\title{
Komunální odpadní voda jako diagnostické médium
}

\section{VĚRA OČENÁŠKOVÁ}

Klíčová slova: epidemiologie odpadních vod - odpadní vody - alkohol - drogy -

léčiva - nikotin - ftaláty - rezidua pesticidů - biomarkery

\section{SOUHRN}

Přispěvek nastiňuje možnosti využití epidemiologického prrístupu k analýze komunálních odpadních vod k monitoringu životního stylu obyvatelstva, stravovacích návyků, dopadů stavu životního prostředí na člověka, hodnocení zdravotního stavu populace a sledování spotřeby nezákonných drog a dalších látek v monitorované populaci. Jeho cílem je upozornit na potřebu věnovat se tomuto vědnímu oboru více i v České republice.

\section{ÚVOD}

Získat nové údaje o tom, co všechno se v životním prostředí vyskytuje, je ve své podstatě čím dál tím jednodušší. Instrumentální technika se bouřlivě vyvijíi, je stále citlivější a citlivější, obsluha přístrojů se zjednodušuje. V jednom analytickém běhu stanovujeme stovky sloučenin najednou, a to v nanogramových i subnanogramových množstvích. Stanovujeme látky známé (target analysis), hledáme dalši látky (non-target screening), abychom je následně již jako známé látky mohli dále sledovat. Takto získaná data většinou porovnáme s legislativou, s normami, vyhláškami, maximálními reziduálními limity a zjistíme, zda analyzovaný vzorek vyhovuje či nevyhovuje požadovaným parametrům.

Na naměřená data můžeme ale pohlížet i jiným způsobem. Epidemiologický prístup k analýze komunálních odpadních vod (wastewater based epidemiology - WBE) je príkladem jiného využití naměřených dat. Základ WBE byl položen na přelomu let 1999 až 2000 vyslovením hypotézy, že ke komunální odpadní vodě Ize přistupovat jako ke zředěnému vzorku moči [1, 2] a poprvé byla aplikována v povodí řeky Pád [3]. Prvními látkami, které byly takto sledovány, byly nezákonné drogy, především kokain a jeho metabolity. Cílem bylo zjistit spotřebu nezákonných drog ve sledované populaci zpětnou kalkulací zjištěných koncentrací drog v komunálních odpadních vodách. Obecný princip nového prístupu k monitorování a zpřesňování odhadu prevalence a uživání drog $\checkmark$ populaci metodou epidemiologie odpadních vod - sewage epidemiology byl popsán ve zvláštní zprávě Evropského monitorovacího centra pro drogy a drogové závislosti (EMCDDA) z roku 2008 [4]. Nejvýznamnější analytickou metodou používanou k měření je bezpochyby kapalinová chromatografie ve spojení s hmotnostní detekcí.

Od dob svého vzniku se stala WBE plnohodnotnou, velmi rychle se rozvíjející disciplínou, která spojuje práci expertů z mnoha oborů. V celosvětovém měřitku je využívána především jako doplňková metoda k monitoringu spotřeby nezákonných drog, např. v Evropě Ort [5], v Asii Khan [6] nebo Gao [7], $\vee$ Americe Subedi a Kannan [8], v Austrálii Irvine [9].
V moči, a tím i v komunálních odpadních vodách, se vyskytují i další látky (či jejich metabolity), kterým je lidská populace exponována a které jsou v těle metabolizovány, jako např. zákonné drogy a léčiva, kofein, nikotin, ethanol, potravinové a environmentální kontaminanty, ale i specifické biomarkery, které mohou přinášet informace o zdravotním stavu monitorovaného obyvatelstva. Kvantitativní měření těchto látek spolu se zpětnou kalkulací poskytne informaci např. o stravovacích návycích, zdravotním stavu, výskytu chorob, spotřebě alkoholu, léčiv a nikotinu nebo expozici potravinovým a environmentálním polutantům. Zároveň Ize zjistit také trendy v užívání či expozici, at’ už krátkodobé nebo dlouhodobé.

Příklad možných biomarkerů využitelných pro monitoring zdravotního stavu populace prostřednictvím WBE uvádějí Thomas a Reid [10]. Tyto biomarkery rozdělují do čtyř skupin. První skupina slouží k monitoringu životního stylu, druhá ke sledování stravovacích návyků, další k hodnocení zdravotního stavu populace a výskytu chorob, poslední je zaměřena na dopady stavu životního prostředí na člověka (expozice pesticidům, PAH a aflatoxinům). Autoři upozorňují na obrovský potenciál epidemiologického prístupu k analýze komunálních odpadních vod, stejně jako Kasprzyk-Hordern [11].

\section{ALKOHOL, DROGY, LÉČIVA, NIKOTIN}

Sledováním spotřeby alkoholu v Norsku prostřednictvím specifických biomarkerů ethylsulfátu a ethylglukuronidu v komunální odpadní vodě se zabývají Reid a kol. [12] a doporučují využití této metody ke sledování efektivity preventivních kampaní zaměřených na snižení spotřeby alkoholu.

Venkatesan a Halden navrhují využít čistírny odpadních vod jako „observatoř" pro predpověd’ zdravotního a environmentálního rizika způsobeného antropogenními chemickými látkami [13].

Venhuis s kolegy sledovali spotřebu sildenafilu, léku na erektivní disfunkci, ve třech nizozemských městech. Výsledky porovnali s množstvím předepisovaného farmaka. Z porovnání obou údajů usuzují, že cca $60 \%$ sildenafilu bylo pořízeno na černém trhu [14].

K monitoringu spotřeby nikotinu v České a Slovenské republice využili epidemiologický prístup k analýze odpadních vod [15]. Z výsledků týdenního monitoringu celkem $v$ sedmi městech byla zpětnou kalkulací využívající specifický korekční faktor vypočtena spotřeba cigaret v České, resp. Slovenské republice a výsledky byly porovnány s oficiálními statistikami o spotřebě cigaret. Shoda mezi výsledky byla velmi dobrá. Obdobným postupem monitorovali spotřebu nikotinu (a cigaret) v osmi italských městech Castiglioni a kol. [16]. Oba způsoby zjištění spotřeby cigaret se vhodně doplňují, epidemiologický príistup umožňuje sledovat trendy ve spotřebě v téměř reálném čase a účinnost 
opatření směřujících ke snížení spotřeby tabáku. V Belgii (město Lier) monitorovali spotřebu nikotinu a alkoholu pomocí epidemiologického prístupu van Vel a kol. [17].

Baz-Lomba a kol. porovnávali množství nelegálních drog, alkoholu, nikotinu a kofeinu $v$ odpadních vodách s údaji zjištěnými jiným způsobem (prodej, zabavené drogy, spotřeba). Pro léčiva a kokain byla prokázána dobrá shoda výsledků, u ostatních látek je třeba ve výzkumu pokračovat [18].

První mezinárodní studii srovnávající spotřebu alkoholu zjištěnou prostřednictvím epidemiologického přístupu ke komunálním odpadním vodám v celkem 20 městech Evropy, Austrálie a Kanady prezentovali Ryu a kol. [19]. Opět bylo prokázáno, že epidemiologický prístup k analýze odpadních vod je významným doplňujícím nástrojem pro sledování spotřeby alkoholu na komunální úrovni.

\section{PESTICIDY}

Nový přístup k biomonitoringu prezentují Rousis a kol. [20, 21]. V komunální odpadní vodě z několika italských měst sledovali př́tomnost humánních metabolitů alkylfosfátů, pyrethroidů, chlorpyrifosu a chlorpyrifos-methylu. Výsledky dokumentují vysokou expozici populace pesticidním látkám běžně používaným k ochraně zemědělských plodin, průmyslovým a domácím účelům. $\checkmark$ rámci Evropy sledoval Routis se spoluautory specifické biomarkery triazinů, organofosfátů a pyrethroidů v osmi evropských městech a státech. Nejvyšší hodnoty byly zjištěny pro organofosfáty, nejnižší pro triaziny. $V$ některých městech byla populace vystavena predevším působení pyrethroidů, $v$ dalších prevládaly organofosfáty. Výsledky byly v dobré korelaci s národními statistikami o prodeji pesticidních látek a dokumentují vhodnost využití tohoto př́stupu ke sledování expozice populace pesticidním látkám [22].

\section{FTALÁTY}

Další skupinou látek, kterou je možno tímto způsobem sledovat, jsou ftaláty. Možné využití sledování metabolitů ftalátů $\vee$ komunální odpadní vodě pro časoprostorové studie expozice populace těmto sloučeninám a identifikaci více ohrožených oblastí předpokládají Gonzáles-Mariňo a kol. [23].

\section{ZÁVĚR}

Tento príspěvek uvádí pouze príklady možností epidemiologického prístupu k odpadním vodám. Současný stav a budoucí perspektivy využití měěení biomarkerů v odpadních vodách jako nového zdroje epidemiologických informací publikuje v podrobném souhrnném článku skupina badatelů, kteří se této problematice věnují dlouhodobě [24]. Jak již bylo řečeno, epidemiologický přístup k analýze odpadních vod je velmi rychle se rozvíjející multidisciplinární obor, který otvírá mnoho dalších možností ke sledování životního stylu a zdraví populace. Je třeba provést ještě další výzkum, především je nutno věnovat pozornost chování biomarkerů v kanalizační síti, např. jejich schopnosti vázat se na suspendované částice př́tomné v odpadní vodě, vliv pH, teploty vody v systému či dobu zádrže v této síti, než bude možno WBE adekvátně aplikovat. Bylo by vhodné i v České republice této problematice věnovat více pozornosti.

Príspěvek byl publikován ve sborníku konference Hydroanalytika 2017, ISBN-978-80-904986-3-1.

\section{Literatura}

[1] DAUGHTON, C.D. and TERNES, T.A. Pharmaceutical and personal care products in the environment: Agent of subtle Change? Environ. Health perspect., 1999, No. 107, p. 907-938.

[2] DAUGHTON, C.G. Illicit drugs: contaminants in the environment and utility in forensic epidemiology. Rev. Environ. contam. toxicology., 2001, No. 210, p. 59-110.

[3] ZUCCATO, E., CHIABRANDO, CH., and CASTIGLIONI, S., CALAMARI, D., et al. Cocaine in surface waters: a new evidence-based tool to monitor. Environmental Health: A Global Access Science Source., 2005, 4, p. 14. DOI: 10.1186/1476-069X-4-14. ISSN 1476069x. Dostupné také z: http://www. ehjournal.net/content/4/1/14

[4] FROST, N. Assessing illicit drugs in wastewater: potential and limitations of a new monitoring approach. Luxembourg: Office for Official Publications of the European Communities, 2008, $100 \mathrm{p}$. EMCDDA insights series, 9. ISBN 92-916-8317-5.

[5] ORT, CH., VAN NUIJS, A.L.N., BERSET, J.D., BIJLSMA, L., et al. Spatial differences and temporal changes in illicit drug use in Europe quantified by wastewater analysis. Addiction, 2014, vol. 109, No. 8, p. 1338-1352. DOI: 10.1111/add.12570. ISSN 09652140. Dostupné také z: http://doi.wiley.com/10.1111/ add. 12570

[6] KHAN, U., VAN NUIJS, A.L.N., LI, J., et al. Application of a sewage-based approach to assess the use of ten illicit drugs in four Chinese megacities. Science of The Total Environment., 2014, 487, p. 710-721. DOI: 10.1016/j.scitotenv.2014.01.043. ISSN 00489697. Dostupné také z: http://linkinghub.elsevier.com/ retrieve/pii/S0048969714000527

[7] GAO, J O'BRIEN, J., LAL, FY, VAN NUIJS, A.L.N.,HE, J., et al. Could wastewater analysis be a useful tool for China? - A review. Journal of Environmental Sciences., 2015, 27, p. 70-79. DOI: 10.1016/j.jes.2014.09.025. ISSN 10010742. Dostupné také z: http://linkinghub.elsevier.com/retrieve/pii/S1001074214002381

[8] SUBEDI, B. and KANNAN, K. Mass Loading and Removal of Select Illicit Drugs in Two Wastewater Treatment Plants in New York State and Estimation of Illicit Drug Usage in Communities through Wastewater Analysis. Environmental Science, 2014, vol. 48, No. 12, p. 6661-6670. DOI: 10.1021/es501709a. ISSN 0013-936x. Dostupné také z: http://pubs.acs.org/doi/abs/10.1021/es501709a

[9] IRVINE, R.J., KOSTAKIS, CH., FELGATE, P.D., JAEHNE, E.J., et al. Population drug use in Australia: A wastewater analysis. Forensic Science International. 2011, vol. 210, No. 1-3, p. 69-73. DOI: 10.1016/ j.forsciint.2011.01.037. ISSN 03790738. Dostupné také z: http://linkinghub.elsevier.com/retrieve/pii/ S0379073811000521

[10] THOMAS, K.V. and REID, M.J. What Else Can the Analysis of Sewage for Urinary Biomarkers Reveal About Communities? Environmental Science., 2011, vol. 45, No. 18, p. 7611-7612. DOI: 10.1021/es202522d. ISSN 0013-936x. Dostupné také z: http://pubs.acs.org/doi/abs/10.1021/es202522d

[11] KASPRZYK-HORDERN, B., BIJLSMA, L., CASTIGLIONI, S., COVACI, A., et al. Wastewater-based epidemiology for public health monitoring. Water and Sewerage Journal, 2014, 4, p. 25-26.

[12] REID, M.J., LANGFORD,K.H., MØRLAND, J., and THOMAS, K.V. Analysis and Interpretation of Specific Ethanol Metabolites, Ethyl Sulfate, and Ethyl Glucuronide in Sewage Effluent for the Quantitative Measurement of Regional Alcohol Consumption. Alcoholism: Clinical and Experimental Research. 2011, vol. 35, No. 9. DOI: 10.1111/j.1530-0277.2011.01505.x. ISSN 01456008. Dostupné také z: http://doi.wiley. $\mathrm{com} / 10.1111 / \mathrm{j} .1530-0277.2011 .01505 . x$

[13] VENKATESAN, A.K. and HALDEN, R.U. Wastewater Treatment Plants as Chemical Observatories to Forecast Ecological and Human Health Risks of Manmade Chemicals. Scientific Reports. 2014-1-16, 4, DOI: 10.1038/srep03731. ISSN 2045-2322. Dostupné také z: http://www.nature.com/doifinder/10.1038/ srep03731

[14] VENHUIS, B.J., DE VOOGT, P., EMKE, E., CAUSANILLES, A., and KEIZERS, P.H.J. Success of rogue online pharmacies: sewage study of sildenafil in the Netherlands. BMJ., 2014, vol. 349. No. jul019, g4317-g4317. DOI: 10.1136/bmj.g4317. ISSN 1756-1833. Dostupné také z: http://www.bmj.com/cgi/ doi/10.1136/bmj.g4317

[15] MACKUL'AK, T., BIROŠOVÁ, L., GRABIC, R., ŠKUBÁK, J. and BODÍK, I. National monitoring of nicotine use in Czech and Slovak Republic based on wastewater analysis. Environmental Science and Pollution Research., 2015, vol. 22, No. 18, p. 14000-14006. DOI: 10.1007/s11356-015-4648-7. ISSN 0944-1344. Dostupné také z: http://link.springer.com/10.1007/s11356-015-4648-7

[16] CASTIGLIONI, S., SENTA, I., BORSOTTI, A., DAVOLI, E., and ZUCCATO, E. A novel approach for monitoring tobacco use in local communities by wastewater analysis. Tobacco Control., 2014, vol. 24, No. 1, p. 38-42. DOI: 10.1136/tobaccocontrol-2014-051553. ISSN 0964-4563. Dostupné také z: http:// tobaccocontrol.bmj.com/lookup/doi/10.1136/tobaccocontrol-2014-051553

[17] VAN WEL, J.H.P., GRACIA-LOR, E., VAN NUIJS, A.L.N., et al. Investigation of agreement between wastewater-based epidemiology and survey data on alcohol and nicotine use in a community. Drug and Alcohol Dependence., 2016, 162, p. 170-175. DOI: 10.1016/j.drugalcdep.2016.03.002. ISSN 03768716. Dostupné také z: http://linkinghub.elsevier.com/retrieve/pii/S037687161600137X

[18] BAZ-LOMBA, J.A., SALVATORE, S., GRACIA-LOR, E., et al. Comparison of pharmaceutical, illicit drug, alcohol, nicotine and caffeine levels in wastewater with sale, seizure and consumption data for 8 European cities. BMC Public Health, 2016, vol. 16, No. 1. DOI: 10.1186/s12889-016-3686-5. ISSN 1471-2458. Dostupné také z: http://bmcpublichealth.biomedcentral.com/articles/10.1186/s12889-016-3686-5

[19] RYU, Y., BARCELÓ, D., BARRON, L.P., et al. Comparative measurement and quantitative risk assessment of alcohol consumption through wastewater-based epidemiology: An international study in 20 cities. Science of The Total Environment., 2016, 565, p. 977-983. DOI: 10.1016/j.scitotenv.2016.04.138. ISSN 00489697. Dostupné také z: http://linkinghub.elsevier.com/retrieve/pii/S0048969716308312 
[20] ROUSIS, N.I., ZUCCATO, E., and CASTIGLIONI, S. Monitoring population exposure to pesticides based on liquid chromatography-tandem mass spectrometry measurement of their urinary metabolites in urban wastewater: A novel biomonitoring approach. Science of The Total Environment., 2016, 571, p. 1349-1357. DOI: 10.1016/j.scitotenv.2016.07.036. ISSN 00489697. Dostupné také z: http:// linkinghub.elsevier.com/retrieve/pii/S0048969716314814

[21] ROUSIS, N.I., ZUCCATO, E., and CASTIGLIONI, S. Wastewater-based epidemiology to assesS human exposure to pyrethroid pesticides. Environment International, 2017, 99, p. 213-220. DOl: 10.1016/j. envint.2016.11.020. ISSN 01604120. Dostupné také z: http://linkinghub.elsevier.com/retrieve/pii/ S0160412016303993

[22] ROUSIS, N.I., GRACIA-LOR, E., ZUCCATO, E., et al. Wastewater-based epidemiology to assess panEuropean pesticide exposure. Water Research, 2017, 121, p. 270-279. DOI: 10.1016/j.watres.2017.05.044. ISSN 00431354. Dostupné také z: http://linkinghub.elsevier.com/retrieve/pii/S0043135417304086

[23] GONZÁLEZ-MARIÑO, I., RODIL,R., BARRIO, I., CELA, R., and QUINTANA, J.B. Wastewater-Based Epidemiology as a New Tool for Estimating Population Exposure to Phthalate Plasticizers. Environmental Science, 2017, vol. 51, No. 7, p. 3902-3910. DOl: 10.1021/acs.est.6b05612. ISSN 0013-936x. Dostupné také z: http://pubs.acs.org/doi/abs/10.1021/acs.est.6b05612

[24] GRACIA-LOR, E., CASTIGLIONI, S., BADE, R., et al. Measuring biomarkers in wastewater as a new source of epidemiological information: Current state and future perspectives. Environment International., 2017, 99, p. 131-150. DOI: 10.1016/j.envint.2016.12.016. ISSN 01604120. Dostupné také z: http://linkinghub.elsevier.com/retrieve/pii/S0160412016306936

\section{Autor}

\section{Ing. Věra Očenášková}

凶vera.ocenaskova@vuv.cz

Výzkumný ústav vodohospodářský T. G. Masaryka, v. v. i.

Příspěvek prošel lektorským řízením

\section{MUNICIPAL WASTEWATER AS A DIAGNOSTIC MEDIUM}

\section{OCENASKOVA, $\mathrm{V}$.}

TGM Water Research Institute, p. r. i.

Keywords: wastewater-based epidemiology - wastewater alcohol - illicit drugs - pharmaceuticals - nicotine phtalats - pesticide rezidues - biomarkers

The paper outlines the possibilities of using the epidemiological approach to the analysis of municipal wastewater to monitor the lifestyle of the population, its dietary habits, the environmental impacts on humans, the assessment of the state of health of the population and monitoring the consumption of illicit drugs and other substances in the monitored population. It aims to draw attention to the need to devote more to this scientific field also in the Czech Republic. 